\title{
Planning Models for a Bus Rapid Transit System (BRT): The Case of Metrobus in Mexico City
}

\author{
Fernando Lámbarry ${ }^{1}$, Mara Maricela Trujillo ${ }^{1} \&$ Luis Arturo Rivas ${ }^{1}$ \\ ${ }^{1}$ Administrative Sciences by the Instituto Politécnico Nacional, México \\ Correspondence: Fernando Lámbarry, Administrative Sciences by the Instituto Politécnico Nacional, México. \\ E-mail: flambarry@ipn.mx
}

Received: May 10, 2013

Accepted: June 14, 2013

Online Published: July 12, 2013

doi:10.5539/ijbm.v8n15p130

URL: http://dx.doi.org/10.5539/ijbm.v8n15p130

\begin{abstract}
This article is about the planningprocess of a bus rapid transit system in Mexico City, called Metrobus.It is a qualitative research that describes the two consolidated models of BRT planning, the one from the Research Board of Transportation based in North America developed cities; and the one from the Institute of Policy for Transportation and Development applied in Latin American cities. Also the study describethe BRT system of the Mexico's Cityin which fieldwork was done based on in-depth interviews to themanagers of the operating carrier companies of the 4 current BRT corridors. The Mexican case shows two variables that are not strongly considered in the studied models and should be incorporated in similar context: the BRT environmental impact and the strategy of consensus withthe BRT operators.
\end{abstract}

Keywords: BRT environmental impact, Metrobús, BRT planning models

\section{Introduction}

The Bus Rapid Transit (BRT) known in México as Metrobus have gained enormous popularity since they contribute to give a modern and orderly image in the cities where the implementation is achieved. In the case of Latin America there are several cities that have this kind of massive transportation, but the available literature agrees with the lack of planning of the transportation systems in general in this region (Rivas et al., 2007). However, the importance of planning are taken up in different kinds of studies, for exampleLevinson et al., (2003) who after studying 26 cases of study developed a guide for the implementation of a BRT system. A work of great interest not only to academics but to public policy makers, managers, directors of transportation and planners. A review of the characteristics of the Bus Rapid Transit projects made by Jarzab, Lightbody and Maeda (2002) they compare the costs and complexity between implementing light rail system versus BRT and conclude that the cost and the determination depend on the context.Polzin, Baltes, and Vuchic (2002) made a critical study of BRT systems as a viable alternative compared to urban trains. They conclude that the BRT is an initial step where there is a possibility of consolidating, later on, urban rail systems which are more expensive and therefore the BRT is a step forward in the urban renewal strategy and in the image of public transportation of a city.

There is an extensive literature on the Latin American experience it highlights the work of: Menckhoff (2005) who after knowing and comparing the experience of different countries including the cities of Quito (Ecuador), Bogota, (Colombia), Santiago (Chile) Leon (Mexico) concluded that BRT systems are a great improvement over traditional bus systems often linked to integral reform processes of public transportation that are much less expensive than light train system and subway but its implementation is complex and requires competent planners and strong political leadership.In another important research Graftieaux and Hidalgo (2009) after comparing 11 cities in Asia and Latin America found that implantation resulted in a reduction of pollution and accidents. Implemented BRT corridors have generally been well received by users, with a relatively low capital investment (1.4 million / $\mathrm{km}$ to 8.2 million euros / km). Systems have faced problems related to planning, implementation and operations, mainly as a result of institutional and financial limitations.

The case of Bogota Colombia, as the first one, has been extensively studied; there are 2510 papers that analyze from multiple operatic approaches, financial, from the quality of service, logistics, among others. Example of this is the work of Ardila (2004), in his research concluded about the planning process and implementation of the BRT systems in Curitiba and Bogotá (which can be interpreted as the consensus reached): institutional 
transformation and concession contracts for bus operators and fee collection.

The exclusively Mexicans papers about the BRT systems are very scarce on literature. Some international organizations such as the Transportation Research Board, the German Technical Cooperation Agency and the Institute for Transportation and Development Policy have studied and documented the processes of planning and implementation of these systems to propose several guidelines. The objective of this study is therefore to analyze the planning and implementation of the Metrobus in Mexico City from its processes and theoretical models.

\subsection{BRT Systems and the Mexican Context}

The Metrobus system of Mexico City is currently composed by four corridors, Line 1: Indios Verdes-El Caminero, Line 2: Tacubaya-Tepalcates, Line 3: Tenayuca-Etiopia and Line 4: Buenavista-Aeropueto, as a result of the materialization of a policy of public transportation system called "Public Transportation Corridors of Passengers of the Gobierno del Distrito Federal" (Gobierno del Distrito Federal, 2004a). However, the challenge of implementing this type of transport is not less in most Mexican cities. Iracheta (2006) warns that transport organizations have been built from political relationships whose influence is reinforced by its important role in the daily mobility of cities, using political influence to negotiate the continuation of its operation often unpunished and outside of laws and regulations that require them to provide a decent service to the public, providing massive a service that cannot be suspended, giving them advantageous bargaining power with governments, preventing the implementation of new policies.

Another problem that has not been studied in depth is the discretionary granting of concessions and adjudication processes without studies that demonstrate a balance of supply and demand to organizations that are not formally constituted companies, benefiting related to politicians groups in power and establishing corporate relationships to the detriment of the public interest. However, a first approach to this problematic situation lies in studying the processes of planning Metrobus system, as is the purpose of this study.

\section{Method of Investigation}

It is a descriptive qualitative research in order to describe and document the planning process in the Metrobus system implementation in Mexico City. Methodologically, the study has two parts, a documentary describing the main models of planning BRT systems reported in the literature and the other describing BRT systems in Mexico City their projects, studies and planning stages made in Metrobus lines from the planning model previousthat involved fieldwork based on in-depth interviews with managers of carriers operating companies of the four corridors of the current system and decentralized organization Metrobus who is in charge of its management.

The planning BRT models reported in the literature were analyzed under the following categories:

- Model description: empirical, stages and activities.

- Assessment of the Model: strengths and weaknesses.

The BRT systems in Mexico City were analyzed under their projects, studies and planning stages made in Metrobus lines contrasting them withthe BRT planning models.

\section{Models of Planning and Implementation of BRT}

There are few existing models documented in the international literature on the planning and implementation of systems of bus rapid transit. The following are the four most important:

1) Transportation Research Board model (TRB) 2003.

2) German Technical Cooperation model (GTZ) 2003

3) Sustainable Transport Center model (CTS) 2005.

4) Institute for Transportation and Development Policymodel (ITDP) 2010.

Only two of these models consolidated principles of the planning process since the ITDP model (model 4) is the latest and extended version proposed by the German Technical Cooperation Agency, the first two versions were developed by Wright and published by GTZ (Institute for Transportation and Development Policy, 2010a).

The Model of Sustainable Transportation Center, more than a model, describes the Mexican context and the integration of four key areas: 1. Technicians, 2. Institutionals, 3. Economic and financial and 4. Urban and social, which are very generic, lightly documented and without empirical evidence to support them.

Therefore only will be described the models considered as consolidated: The model of the Transportation Research Board TRB and model of the Policy Institute for Transportation and Development. 


\subsection{Model of the Transportation Research Board TRB (2003)}

The Transportation Research Board is one of the major divisions of the National Research Council of the United States, is a private, nonprofit institution that promotes innovation and progress in transportation by promoting and conducting research into this area (Transportation Research Board, 2012).

\subsubsection{Model Description}

Empirical evidence: In the framework of the Transit Cooperative Research Program (TCRP) and with the leadership of the consultants Levinson, Zimmerman, Clinger, Gast, Rutherford and Bruhn, the Board proposed a guide for the planning and implementation of BRT, which emerged from a compendium of worldwide similar experiences of 26 cases of study in the following cities:

- North America: Boston, MA. Charlotte, NC. Cleveland, OH. Eugene, OR. Hartford CT. Honolulu, HI. Houston, TX. Los Angeles, CA. Miami, FL. New York, NY. Ottawa, ON. Pittsburgh, PA. Seattle, WA. Vancouver, BC.

- Australia: Adelaide. Brisbane. Sydney.

- $\quad$ Europe: Leeds, United Kingdom. Rouen, France. Runcorn, United Kingdom.

- South América: Belo Horizonte, Brazil. Bogotá, Colombia. Curitiba, Brazil. Porto Alegre, Brazil. Quito, Ecuador. Sao Paulo, Brazil.

However, the guidelines that the guide sets out that are focused on the best practices and context of American cities.

Activities and stages proposed: The process involves the following activities:

1) Planning. 1. System development process. 2. Established planning procedures required by the Federal Transit Agency. 3. Terms of service desired.

2) Roadways of the corridor. 1. Configuring of the road. 2. Cost of performance and passenger capacity. 3 . Bus Design parameters: dimensions, performance, interior. 4. Operations in mixed traffic. Considerations of operation according to the configuration of the road.

3) Traffic Engineering. 1. Traffic control: restricting parking and loading control. 2. Control of turns to the left and / or right. 3. Special signage and displays.

4) Stations and infrastructure. 1. System design, urban and integral: location and spacing of stations. 2. Design of stations: the operation factors. 3. Collection of the fee. 4. User facilities. 5. Lighting. 5. Security. 6. Features of the platform. 7. Stations configuration 8. Intermodal stations and terminals. 9. Park and ride facilities. 10. Ancillary services.

5) BRT vehicles. 1. Capacity and level of service. 2. Emissions and pollution. 3. Guidance system. 4. Image. 5. Maintenance and costs.

6) Intelligent Transportation Systems (ITS). 1. Automatic vehicle location system (AVL). 2. Passenger information system. 3. Transit priority signaling. 4. Automatic passenger counters. 5. Electronic fare collection cards. 6. Bus Technology guidance. 7. Collision detection system. 8. Bus coupling section. 9. Benefits and costs.

7) Bus operation and service. 1. Service design. 2. Fare collection. 3. Marketing service.

8) Funding and implementation. 1. Estimated benefits and costs of the system. 2. Capital costs and operation. 3. Sources and financing options. 4. Project delivery options. 5. Incremental development of BRT projects.

6. Institutional arrangements. 7. Complementary public policies to the system.

\subsubsection{Assessment of the Model}

Strengths: The planning guide is focused on each of the components of the BRT rather than on the phases of the planning process itself, except for those referred as planning, financing and implementation; contemplates detailed guidance from a complete and integral vision for each of them. Analyzes transportation alternatives to validate the best option that should be implemented and the BRT in terms of cost-benefit and impact if it's chosen.

Considers that in many projects of BRT as well as transport properties, operate through several limits of jurisdiction (federal, state or regional) and involve the participation of multiple stakeholders, among which are: federal, state and regional transit agencies (related to the environment, transportation and economic 
development) private sector representatives and transport operators so that their planning is approached from the perspective of the communities and those organizations involved.

These groups of interest often bring their own priorities for the process of planning, for that reason, for the project to be successful, requires to establish agreements regarding infrastructure, technology, operations and responsibilities assumed in the BRT.

Emphasizes as lessons on the implementation of system, the essential will of the community to participate in the public decision-making process to endorse, support and facilitate its implementation; notes as key the speed of BRT, making it necessary to establish in parallel complementary policies of transit to achieve it, highlights the potential of this transport on the planning of soil use and in the urban development trend, also indicates the sources of financing and acquisition of funds for the implementation process, operation and maintenance.

Weaknesses: It is a relatively old model that was proposed in 2003 and has not been updated, is based on a compendium of case studies in which focuses on best practices and experiences in the planning process and implementation of BRT mainly in American cities, therefore this model is more suitable to cities with a high level of development.

\subsection{The Institute for Transportation and Development Policy Model ITDP (2010)}

The Institute for Transportation and Development Policyis an international NGO that works with cities worldwide to achieve transportation solutions that reduce emissions of greenhouse gases, reduce poverty and improve the quality of urban life. It focuses particularly on promoting public transportation options that are environmentally, economically and socially sustainable in countries in developing and transition economies.

More recently, ITDP has played a key role in the design and construction of bus rapid transit in the world, proposing a model developed with support from the William and Flora Hewlett Foundation, the Global Environment Fund, the United Nations Environment Programme and the German Technical Cooperation Agency (Institute for Transportation and Development Policy, 2010b).

\subsubsection{Model Description}

Empirical evidence: It was designed by various transport consultants from several international institutions, among which are Fjellstrom and Hook from the ITDP, Kunming from the Institute of Urban Transport, Litman from the Victoria Institute for Transport Policy, Zimmerman Menckoff from the World Bank, Pardo from the German Technical Cooperation Agency and Wrightfrom from the University College London. It is a new edition published by Wright and the German Technical Cooperation Agency and is a compilation of international experience which includes the city of Curitiba who is considered the origin of the BRT, but is mainly based on the experience of the implementation team trans Milenio SA in Bogota.

Activities and stages proposed: Aligns its planning process through six main components:

1) Project preparation: 1. Project initiation. 2. Technological options. 3. Project organization. 4. Demand analysis. 5. Selecting corridors. 6. Communication.

2) Operational design: 1. Network design and service. 2. System capacity and Speed: Requirements corridor capacity. Vehicle size. Interface-car station. 3. Intersections and signal control: Evaluation of intersections. Restrictions on return. Movements around the BRT. Transit priority signals. 4. Service to the user: User information. Professionalism of the system. Personal safety and road. Features.

3) Physical design: 1. Infrastructure: 1. Lanes. Stations. Terminals and courtyards of confinement. Infrastructure cost. 2. Technology: Technology of the vehicle. Collection of the fee. Intelligent Transportation Systems.

4) Integration: 1. Modal integration.

5) Business Plan: 1. Business structure: Business model. Transformation of structures. Institutional organization. 2. Operational costs: operational cost components. Distribution of income. Fee. 3. Financing. 4. Marketing.

6) Evaluation and implementation: 1. Impact evaluation. 2. Implementation plan.

\subsubsection{Assessment of the Model}

Strengths: It is an integral model of planning and implementation sufficiently documented from multiple investigations that constitutes it, is a collaboration of several international organizations specialized in sustainable transportation. The six phases of planning are clearly defined, as well as associated by components of BRT as by a planning process per se, that beyond the stages of physical and operational design, the 
integration and business plan of the model where the activities and factors arerelated to the major components and operation of the system, includes a preliminary stage of preparation and organization of the project up to the evaluation and implementation of the BRT.

The description of the activities of each of the stages of the detailed and model is referred to as the most important activity in BRT planning, is the political will accentuated by a public desire to have an improved transit system. To find acceptance and community support the model includes an analysis of the key players (stakeholders) and a public participation process. Impact analysis is integral to consider not only the impact on traffic, but also in the economic, social, environmental and urban redesign.

Weaknesses: This model is based from the experiences in three Latin American cities (Curitiba in Brazil, Bogota in Colombia and Quito in Ecuador) which were the first and the most representative in the implementation of this type of transport systems. Although this model gives importance to the inclusion of existing operators and affected by the new BRT, does not delve into the subject and leaves no alternative to those who may lose their jobs and livelihood.

Based on the analysis categories a comparison of the models described is shown in Table 1.

Table 1. Comparative models TRB and ITDP

\begin{tabular}{|c|c|c|c|c|}
\hline Model & Empirical evidence (cities) & Phases & Strengths & Weaknesses \\
\hline 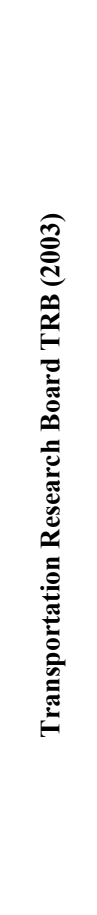 & $\begin{array}{l}\text { • North America: Boston, } \\
\text { MA. Charlotte, NC. Cleveland, } \\
\text { OH. Eugene, OR. Hartford, CT. } \\
\text { Honolulu, HI. Houston, TX. Los } \\
\text { Angeles, CA. Miami, FL. New } \\
\text { York, NY. Ottawa, ON. Pittsburgh, } \\
\text { PA. Seattle, WA. Vancouver, BC. } \\
\text { • Australia: Adelaide. } \\
\text { Brisbane. Sydney. } \\
\text { • } \quad \text { Europe: Leeds, United } \\
\text { Kingdom. Rouen, France. } \\
\text { Runcorn, United Kingdom. } \\
\text { • } \quad \text { South America: Belo } \\
\text { Horizonte, Brazil. Bogotá, } \\
\text { Colombia. Curitiba, Brazil. Porto } \\
\text { Alegre, Brazil. Quito, Ecuador. } \\
\text { Sao Paulo, Brazil. }\end{array}$ & $\begin{array}{l}\text { 1. Planning. } \\
2 . \quad \text { Roads of the } \\
\text { corridor. } \\
\text { 3. Transit } \\
\text { Engineering. } \\
4 . \quad \text { Stations and } \\
\text { infrastructure. } \\
\text { 5. BRT } \\
\text { vehicles. } \\
6 . \quad \text { Intelligent } \\
\text { Transportation } \\
\text { Systems. } \\
7 . \quad \text { Bus } \\
\text { operation and } \\
\text { service. } \\
8 . \quad \text { Financing } \\
\text { and } \\
\text { implementation. }\end{array}$ & $\begin{array}{l}\text { Focused mostly towards } \\
\text { each of the components of } \\
\text { the BRT. Includes a } \\
\text { preliminary stage } \\
\text { planning and another of } \\
\text { financing and } \\
\text { implementation. } \\
\text { Emphasizes as essential } \\
\text { the community will to } \\
\text { participate publically to } \\
\text { support and facilitate its } \\
\text { implementation. } \\
\text { Points as key the speed of } \\
\text { the BRT making it } \\
\text { necessary to establish } \\
\text { parallel transit } \\
\text { complementary policies. } \\
\text { Highlights the potential of } \\
\text { this transport on land use } \\
\text { planning and on the } \\
\text { development trend. } \\
\text { It's of a prospective kind. }\end{array}$ & $\begin{array}{l}\text { - } \\
2003 \text { without recent } \\
\text { update. } \\
\text { Based in case studies } \\
\text { mainly in North American } \\
\text { cities so its application } \\
\text { works in similar contexts. }\end{array}$ \\
\hline
\end{tabular}




\begin{tabular}{|c|c|c|c|c|}
\hline 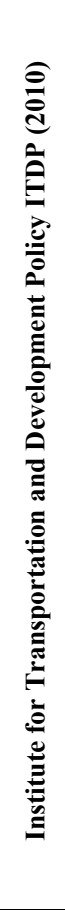 & $\begin{array}{l}\text { - } \quad \text { Based mainly on the } \\
\text { experience of the implementation } \\
\text { team of TransMilenio S.A. in } \\
\text { Bogotá. } \\
\text { - } \quad \text { Latin America: Curitiba, } \\
\text { Brazil. Bogotá, Colombia, Quito, } \\
\text { Ecuador. }\end{array}$ & $\begin{array}{l}\text { 1. Project } \\
\text { preparation. } \\
2 . \quad \text { Operational } \\
\text { design. } \\
\text { 3. Physical } \\
\text { Design. } \\
4 . \quad \text { Integration. } \\
5 . \quad \text { Business } \\
\text { Plan. } \\
6 . \quad \text { Evaluation } \\
\text { and implementation }\end{array}$ & $\begin{array}{l}\text { - Model extensively } \\
\text { documented. } \\
\text { - Result of the } \\
\text { collaboration of several } \\
\text { specialized international } \\
\text { organizations. } \\
\text { - } \quad \text { Planning related to the } \\
\text { components and operation of } \\
\text { the system, presents a business } \\
\text { plan. } \\
\text { - } \quad \text { Includes a preliminary } \\
\text { stage of preparation and } \\
\text { organization of project that } \\
\text { analyzes the stakeholders and } \\
\text { another of evaluation and } \\
\text { implementation (impact } \\
\text { analysis). } \\
\text { - } \quad \text { Emphasizes the political } \\
\text { will accentuated by a public } \\
\text { desire as the most important } \\
\text { activity of the project. } \\
\text { - It is of a reactive type }\end{array}$ & $\begin{array}{l}\text { - It is based from the } \\
\text { experiences in three Latin } \\
\text { American cities. } \\
\text { - Recommends, by political } \\
\text { terms, advisable to include at } \\
\text { least one affected existing } \\
\text { operator in the BRT operation, } \\
\text { but does not delve into the } \\
\text { subject. }\end{array}$ \\
\hline
\end{tabular}

Source: Own elaboration with material of mentioned the organizations.

The models shown in Table 1, although organized differently, coincide in the planning for BRT components, in its infrastructure, operation and integration, as well as a preliminary stage of planning in relation to the search for community support and of the groups involved to the project and a final stage on the financing and implementation of BRT.

The main difference originates from the experiences and case studies that support them, the one proposed by the Transportation Research Board applies to developed cities where the implementation of the BRT has a planning context controlled of a prospective type.

In the case of Latin American cities in process of development, the Institute for Transportation and Development PolicyModel is more applicable as it possesses the evidence of been used in Bogota Colombia, however it should be adapted to each case making emphasis on aspects of consensus among the key players involved.

The main conclusion obtained after comparing the models of planning for BRT systems is that its implementation lies more in the sociocultural context that exists in the city where it will be implemented.

Of the two models the most complete and appropriate to Mexican cities is the one proposed by the Institute for Transportation and Development Policy.

\section{The Case of the Metrobus in Mexico City}

The granting of concessions of public passenger transportation in the Transport Regulations of the Gobierno del Distrito Federal states in Article 17, that prior to granting concessions to private individuals, the Ministry of Transportation and Highway Administration (Secretaría de Transporte y Vialidad, 2011) has to publish a Declaration of Necessity and indicates, in Article 19, that preliminarily to this publication, a study has to be issued containing the balance between the offer and demand, including: results of the study of step frequency and loads in thesections with higher demand of the route and in the peak demand period. Likewise in Article 22 specifies the content of the technical studies: demand and the respective operating programs that support the features of the route, infrastructure, physical space, coverage and area influence for service provision, the characteristics of the kind of vehicle to use and its maintenance, the training program, incentives, fleet renewal and, where appropriate, environmental protection and customer service in addition to the analysis of the potential impact on the operation of the service. Additionally, the Transportation Law of the Gobierno del Distrito Federal in its Article 29, ratifies that before awarding the concession it should be accredit the overall training program that the moral person will apply annually to its employees and the annual program of 
maintenance of the vehicle fleet that will have to provide transportation services.

Although compliance with the law in terms of planning and granting of public passenger transportation in Mexico is often forgotten when there is no vigilant civil society. Documentary evidence of the planning process of the Metrobus appears to have complied with the law because in each of its lines, is composed of specialized studies and projects, consistent with the theoretical basis and normative statutes which by law must be fulfilled, likewise, it shows correspondence with the Institute for Transportation and Development PolicyModel. Table 2 describes the projects and the studies conducted in the four lines where it was able to document the planning process.

Table 2. Projects, studies and planning stages made in Metrobus lines from ITDP model

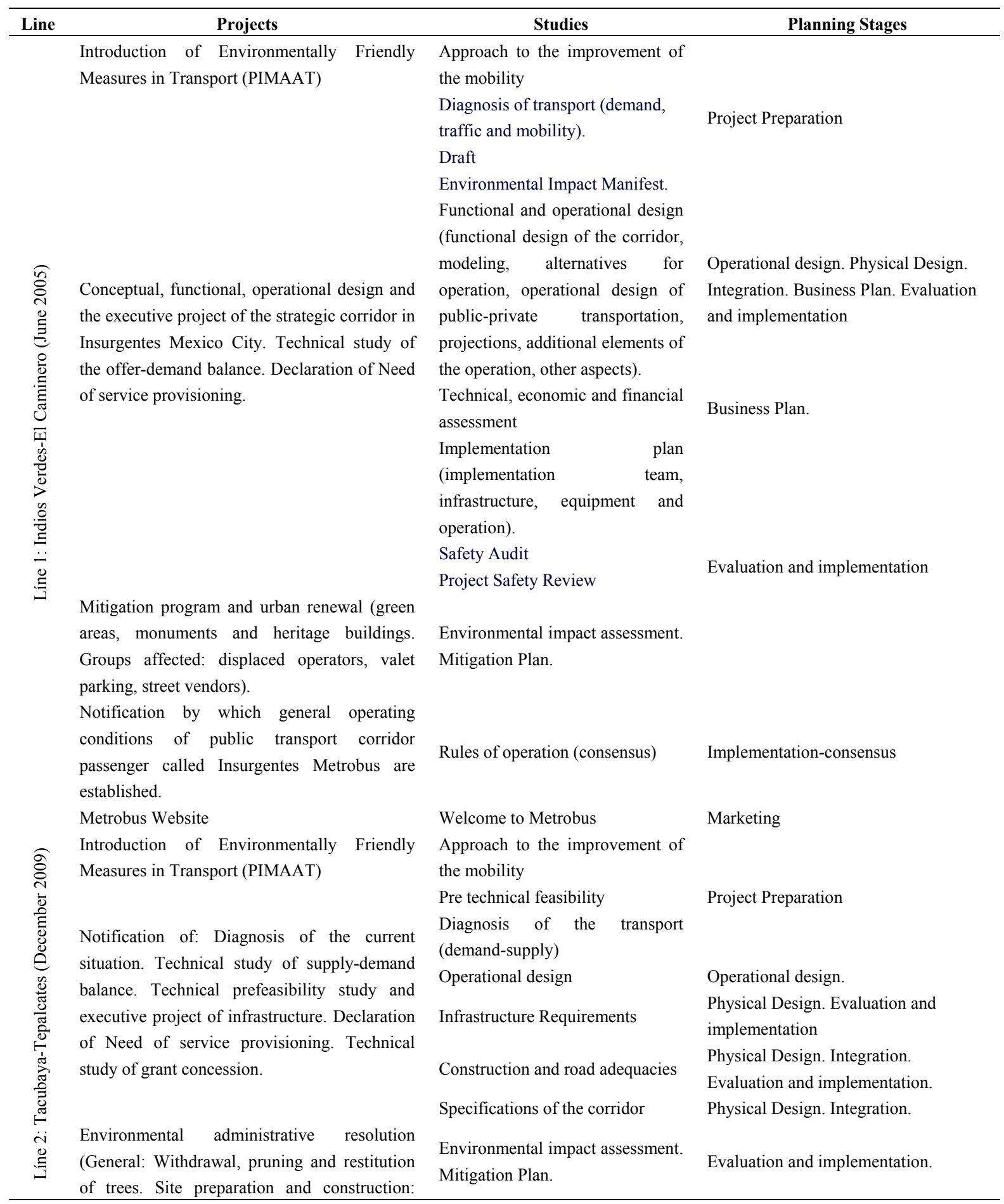


noise emission limits, emission balance,

prevention, noise reduction, wastewater

management and socio-economic field.

Operation and maintenance.)

Metrobus Website

Welcome to Metrobus

Marketing

Source: Own elaboration based on the Gobierno del Distrito Federal, et al., (2004). Gobierno del Distrito Federal, (2004b, 2004c, 2005, 2007a, 2007b, 2008a, 2008b, 2008c, 2010a, 2010b, 2011a, 2011b, 2011c).

The projects and technical studies suggest that the development of a methodological process on the planning and implementation of the analyzed lines of the Metrobus obeyed an orderly and transparent planning process. Two transcendent findings stand out based on the analysis of the planning studies of the Metrobus and by its sociocultural context: The environmental impact assessment and consensus with the operators concerned.

\subsection{Environmental Impact Assessment}

Being Mexico City one of the most polluted cities in the world (Molina and Molina, 1994) provides on its current legislation on environmental issues and specifically on public transportation mobility policies, a number of measures to mitigate the environmental impact. For the case of the implementation of a BRT (Metrobus) is even possible that these measures are capitalized to acquire financing through the sale of carbon credits derived from the reduction of emissions of greenhouse gases in its operation (Institute for Transportation and Development Policy, 2010).

The possibility of affectation to the urban setting and environment, caused by the four lines of the Metrobus and each path trajectories, was evaluated to identify, prevent, mitigate and compensate for the potential damages arising from its implementation, this actions focused on: green areas (reforestation), sidewalks and medians, valet parking and informal trade reorganization, waste handling and protection of monuments and heritage sites; for which agreements with federal dependencies responsible for their protection and integrity were formalized (Gobierno del Distrito Federal, 2007; Secretaría del Medio Ambiente, 2004, 2009, 2007, 2011). On line 1 with the monument of the Indios Verdes and in line 4 that crosses the Historic Center of Mexico City, declared since 1988 by UNESCO as Cultural Heritage of Humanity (Gobierno del Distrito Federal, 2007, 2011).

\subsection{Consensus with Affected Operators}

The potential degree of harm, if services and mobilizations of discontent by the affected operators are suspended, reiterate the importance of including them or assuming the political costs of not doing so (Iracheta, 2006; Institute for Transportation and Development Policy, 2010). Studies conducted identified the following concessionaires and the consensus achieved on the participation in the BRT, are:

- Line 1. Indios Verdes- El Caminero: Only two public transportation organizations stood out in the operation of this corridor, the civil association called Ruta 2 with $62 \%$ of attracting passengers and the decentralized public organism called Passenger Transport Network (RTP) with 38\% (Gobierno del Distrito Federal, 2004b, 2004c). Ruta 2 became the company "Corredor Insurgentes S.A." (CISA) and agreed to a $75 \%$ share, while RTP stayed with the remaining 25\% (Lambarry, Rivas and Trujillo, 2011). In a similar manner, when the line 1 expanded to the southern part, it was identified that RTP captured $20 \%$ of passengers and concessionaires of Ruta 1 with a $71 \%$ uptake; Ruta 76 with the $5.7 \%$ and with $3.2 \%$ Ruta 111 (Gobierno del Distrito Federal, 2007), RECSA was instituted agreeing to a 75\% participation and RTP with a 25\%. (Lambarry, Rivas and Trujillo 2011).

- Line 2. Tacubaya-Tepalcates: on this corridor operated the decentralized public organism of the the Gobierno del Distrito, Sistema de Transporte Eléctrico (STE) with the acquisition of $20 \%$ of the passengers and Rutas with the following percentages of acquisition: Ruta 110 with $21.4 \%$, with $3.4 \%$ Ruta 11 , Ruta 27 with $12.9 \%$, with $12.9 \%$ Ruta 49 and Ruta 53 with $11.7 \%$.

- The operators of Rutas 11, 27, 49 and 53: were civil associations, while Ruta 110 was a moral person organized as a commercial undertaking. (Gobierno del Distrito Federal, 2008). Participation agreements were: Ruta 110 formed GM4 - March 17, S.A.de C.V. with participation of 27.7\%. East West Corridor, SA de CV (COPSA) was constituted by concessionaires of the Rutas 49, 27 and 53 with $20.8 \%$, but it dismantled causing the emergence ofCorredor Tacubaya Tepalcates Inc. (CTTSA) gaining 22.2\% stake. Transportes SAJJ S.A. de C.V. formed by Ruta 11 concessionaires with $12.5 \%$ and RTP instead of STE with 16.6\% (Lambarry, Rivas and Trujillo, 2011). 
- Line 3 Tenayuca-Etiopía: this corridor was operated by the Passenger Transportion Network and it was significantly impinged on their travels by Ruta 1 that in conjunction with Ruta 3 captured $72.5 \%$ of the travelers and Ruta 88 stayed with a 27.5\% (Gobierno del Distrito Federal, 2010), through a process of high opacity and mobilizations some of them sold their concession to the company Movilidad Integral de Vanguardia S.A., while others participate as shareholders in it (Lambarry, Rivas and Trujillo, 2011).

- Line 4 Buenavista-Aeropuerto: They operated both the Metro and the decentralized public bodies STE and RTP and 15 transportation Routes concessioned of the Gobierno del Distrito Federal, the operator 115 and Rutas 1, 2, 3, 7, 9, 12, 17,18, 22, 80, 88, 99, 104, 108. Overall, public bodies and concessionaires had a coverage which ranged from $1 \%$ to $9.5 \%$ of the total length of the corridor; most of their travels $(90.5 \%)$ were performed out of the route. None of which fully took care of the service needs from the area of influence of the corridor (Gobierno del Distrito Federal, 2011). The declaration of public service was published establishing that the concession will be granted to a moral person, which in this case is Centro-Aeropuerto S.A. de C.V, and additionally 10 routes, that spliced in the path of the line, would be relocated and are currently on negotiations (Metrobus, 2011).

Based on the technical studies and by legal mandate, the operation of the Metrobus lines was justified and declared that the need for the concession of the public transportation of passengers for each of the corridors, for operational feasibility, required on most of the cases the participation of the concessionaires with significant journeys on the trace of Metrobus as long as they would constitute as legal entities and were consistent with the new rules of operation for the provision of service, except for line 3 where some of the concessionaires were incorporated as members of a single operator company of the corridor that in the end turned to be unrelated to the public transportation service of passengers and to the area ofoperation, likewise in line 4 , where no existing service significantly impinged and therefore did not integrate any new operator to the concession company.

Line 1, as first corridor implanted, distinguished itself for establishing guidelines to be met by operating companies that join the Metrobus transportation service, in the document entitled operating rules (Gobierno del Distrito Federal, 2005). This document includes most of the consensus reached between the relevant operators and government authorities who implemented it, studied by Lámbarry, Rivas and Trujillo (2012), which corresponding to the phases of the planning process can be associated in: business plan, service operation, physical structure and assessment and are briefly described below.

Business plan:

- Toll system and access control: grant to third parties.

- Participation of the operating companies: shareholding, payment based on the number of miles driven in service, application of respective deductions or rebates, weekly liquidation and additional income for advertising spaces inside their buses according to the provisions of the system image handbook.

- Trust: concentration and distribution of the corridor resources according to the payment priority established by the by the trust agreement itself among the following categories: fiduciary services, the toll system and access control, credit for the payment of buses, services related to the Insurgentes corridor, feeder services, operating companies, regulator, contingent and reserve funds and the others approved by the technical committee of the trust.

- Costs: operational: bus maintenance carried out by the operating companies, infrastructure in charge of government, access control, related services needed to provide the service (cost of electricity consumption, water, cleaning, maintenance and supervision broker) in charge of Metrobus, fiduciary services and of the toll system by the contracted company. Covered by the fee.

Service operation:

- Regulation, supervision, surveillance, scheduling and control: are functions of Metrobus.

- Operating companies committee: their attributions are to review and propose changes to the service operation program of review and reconcile the data of service on mileage of the vehicle fleet.

- Deductions: economic discounts that the regulator applies to the operating companies, for reasons attributable to drivers, for deficiencies related to customer service, those related to buses and infrastructure (courtyards of confinement and maintenance of buses, facilities and equipment).

- Guarantees and insurance: includes risks of force majeure and fortuitous event and liability insurance.

- Feeder routes: in case they participate in them as well. 
Physical structure:

- Government infrastructure: responsible for the construction and maintenance of terminals, stations, confined rail, bases and launchers. The operating companies of the courtyards of confinement, workshop and fuel supply station.

- Vehicular fleet: registration at Metrobus of the buses and drivers, buses on duty $(85 \%$ and $95 \%)$ and reserve ( $5 \%$ and $15 \%)$, fulfillment of technical and functional specifications, approval certificate, variable amount of the fleet according to demand of the corridor, compliance with the program of service operation, system and maintenance, 10 years of useful life, image compliance within all units.

Evaluation:

Environmental management program: includes a maintenance program (quality of workmanship, quality of the parts, contaminants verification program) and hazardous waste management program, with priority for fuels, lubricants and filters.

Regarding the negotiation process in the implementation of each line of the system, they were held individually between each of the operators and government authorities, in return, the operators ceded the revocation of their concessions under the slogan of "we change or get changed" agreed to participate, although these processes do not strictly followed the canons of consensus building it is an approach to them in most cases (except in line 3 where it was not possible to conduct interviews or document these agreements) the affected operators were considered in the operation of the BRT.

\section{Conclusions}

There are two models for planning and implementation of rapid transit buses systems consolidated in the international literature on the subject, planning and implementation of a BRT. Their main difference is their foundation context.

The model proposed by the Transportation Research Board has been used in cities in developed countries where there is a long tradition of clarity and prospecting in the style of urban planning.

The Institute for Transportation and Development PolicyModel emerges from experiences of Latin American cities in process of development where their planning is often reactive and the BRT palliative to a unsustainable transportation problem, in which the affected concessionaires have a role key that may be resistance to the project or the participation in the operation of the new system.

On the Metrobus system in Mexico City the documentation demonstrates a systematic planning process with considerable differences in the implementation of its lines but coincident in phases and activities of theInstitute for Transportation and Development Policy model although without much emphasis on a first reading, it is considered desirable for political reasons to integrate at least one concessionaire concerned with the operation of the new system.

For the Metrobus context there are two lessons learned, in particular the one to include the concerned operators and emphasize on the consensus reached, which is not accented in the studied planning models highlighting two variables to incorporate: the expected environmental impact and the strategy of consensus with the concerned operators.

- The environmental impact: although it can be found in the current legislation on environmental matters of Mexico City, an impact analysis and mitigation measures resulting from the implementation of the BRT focused on green areas: reforestation, sidewalks and medians, valet parking and informal trade reorganization, waste handling that not only focused on the effects of the construction process but also in the long term, additionally the protection of monuments and heritage sites with great historic value formalizing agreements with federal dependencies responsible for their protection and integrity. In line 1 with the monument of the Indios Verdes and in line 4 that crosses the Historic Center of Mexico City, declared by the UNESCO as a Cultural Heritage of Humanity Site. Part of this is consistent with the study by the Institute for Transportation and Development Policy (2010).

- The consensus strategy: the affected operators concessionaires are an actor of great power that must be included in the operation of the corridor. Mostly the dealers were civil associations operating individually with a informally and inefficient functioning however, they were only included to participate in Metrobus the operators that, by their trajectory of service, impinged significantly on the number of transported passengers on the corridor and that would constitute as a company, becoming its informal activity to a financially formal, the same that Ardila (2004) concluded. 
As a result of the analysis to the existing planning models and the case of Metrobus Mexico City, a planning theoretical model is proposed on Figure 1.

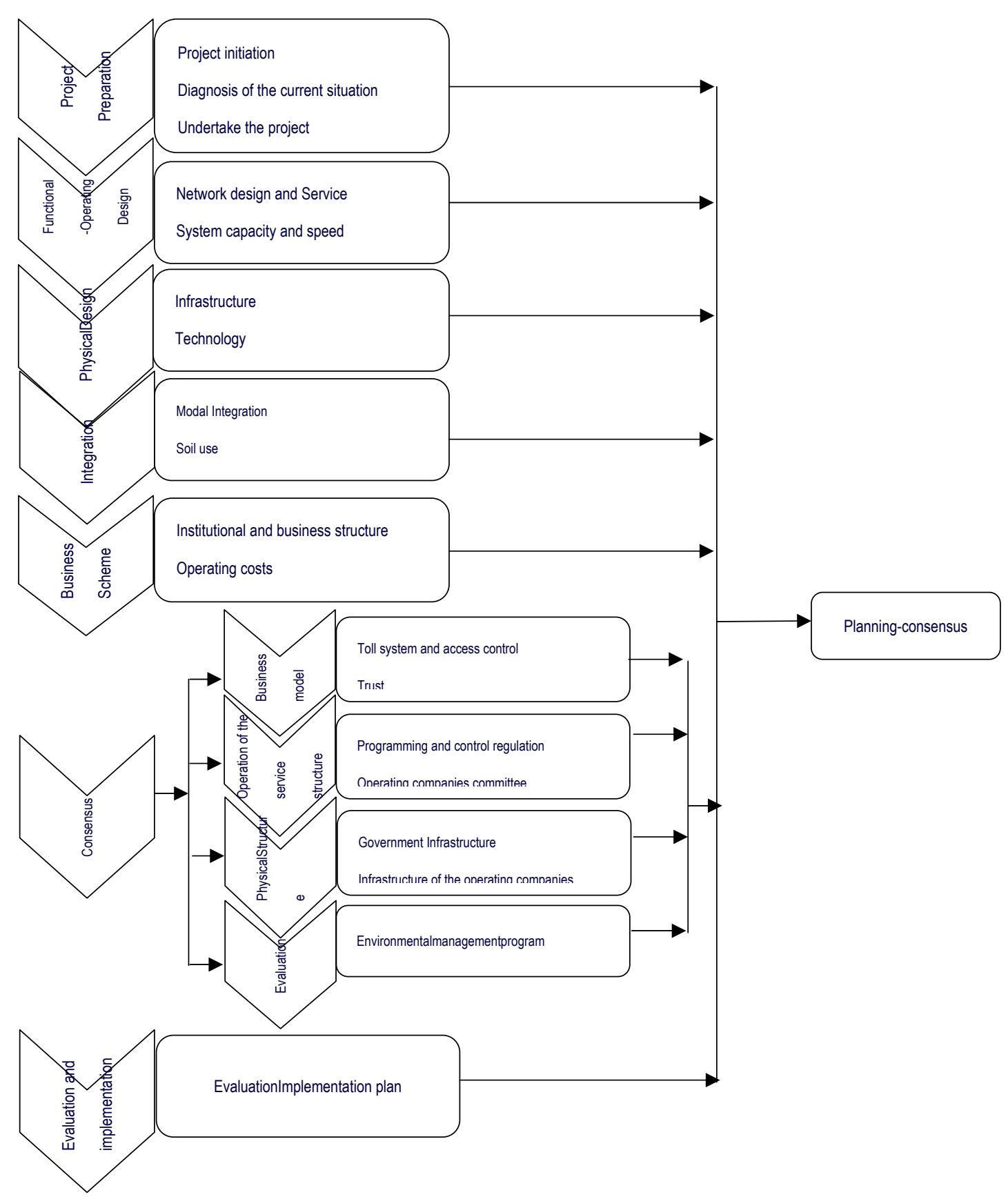

Figure 1. Model of planning and consensus

Source: Own elaboration.

This model is an innovation in the literature on the subject, emphasizing the importance of the process of consensus and their activities often poorly documented and addressed by the planning models BRT systems despite the recognition of the important role played by operators affected by the new system in the successful implementation of the transport (Ardila, 2004; Lámbarry, Rivas \& Peña, 2011).

This proposal comes from the study of existing models; it can be useful as a supplement to consider in the development of BRT systems in Latin America, whose cities have socio-cultural and public transportation 
systems similar to the Mexican case. The model describes the agreements reached between the concessionaires and the government authorities, likewise emphasizes the variable of environmental impact that for Mexico City must be fulfilled by legal mandate and by construction considerations in humanity heritage areas.

\section{References}

Ardila, A. (2004). Transit Planning in Bogota and Curitiba: Roles in Interaccion, Risk and Change. Boston: MIT.

Banco Nacional de Obras y Servicios Públicos. (2010). Programa Apoyo Federal al Transporte Masivo-PROTRAM. Retrieved from http://www.fonadin.gob.mx/wb/fni/programa_de_transporte_urbano

German Technical Cooperation/Sustainable Urban Transport Project (GTZ/SUTP). (2003). Sustainable Transport: A Source Book for Policy-makers in Developing Cities Module 3a: Mass Transit options. Retrieved from http://www.gtz.de/en/themen/28264.htm

German Technical Cooperation. (2012). GTZ. Services. Retrieved from http://www.gtz.de/en/index2.htm

Gobierno del Distrito Federal. (2004a). Secretaría de Transportes y Vialidad. Aviso por el que se aprueba el establecimiento del Sistema de transporte publico denominado "Corredores de transporte público de pasajeros del Distrito Federal. Gaceta Oficial del Distrito Federal. Número 98-Bis. Décimo Cuarta Época. Retrieved from http://www.consejeria.df.gob.mx/uploads/gacetas/Septiembre04_24_98bis.pdf

Gobierno del Distrito Federal. (2004b). Aviso por el que se da a conocer el estudio que contiene el balance entre la oferta y la demanda de transporte público colectivo de pasajeros en la avenida de los Insurgentes del Distrito Federal. Gaceta Oficial del Distrito Federal. Número 456. Décimo Cuarta época. Retrieved from http://www.consejeria.df.gob.mx/uploads/gacetas/index

Gobierno del Distrito Federal. (2004c). Declaratoria de necesidad para la prestación del servicio público de transporte de pasajeros “Metrobús" Insurgentes. Gaceta Oficial del Distrito Federal. Número 139. Décimo Cuarta Época. Retrieved from http://www.consejeria.df.gob.mx/uploads/gacetas/noviembre139.pdf

Gobierno del Distrito Federal. (2005). Aviso por el que se dan a conocerlas condiciones generales de operación del corredor de transporte público de pasajeros denominado Metrobús Insurgentes. Gaceta Oficial del Distrito Federal. Número 35-BIS9. Décimo Quinta Época. Retrieved from http://www.consejeria.df.gob.mx/gaceta/index

Gobierno del Distrito Federal. (2007a). Aviso por el que se aprueba el segundo el segundo corredor de transporte público de pasajeros "Metros Insurgentes Sur" y se establecen las condiciones generales de su operación. Gaceta Oficial del Distrito Federal. Número 120. Décimo Cuarta Época. Retrieved from http://www.consejeria.df.gob.mx/uploads/gacetas/julio/gaceta/index

Gobierno del Distrito Federal. (2007b). Declaratoria de necesidad para la prestación del servicio de transporte público colectivo de pasajeros en el segundo corredor de transporte público de pasajeros "Metrobús Insurgentes Sur". Gaceta Oficial del Distrito Federal. Número 171. Décimo Séptima Época. Retrieved from http://www.consejeria.df.gob.mx/uploads/gacetas/noviembre/gaceta/index

Gobierno del Distrito Federal. (2008a). Aviso por el que se aprueba el corredor de transporte público de pasajeros "Metrobús eje 4 sur" y se establecen las condiciones generales para su operación. Gaceta Oficial del Distrito Federal. Número 361. Décimo Séptima Época. Retrieved from http://www.consejeria.df.gob.mx/uploads/gacetas/junio/gaceta/index

Gobierno del Distrito Federal. (2008b).Aviso por el que se da a conocer el balance entre la oferta y la demanda de transporte público colectivo de pasajeros en el corredor "Metrobús Eje 4 Sur". Gaceta Oficial del Distrito Federal. Número 381. Décimo Séptima Época. Retrieved from http://www.consejeria.df.gob.mx/uploads/gacetas/julio/gaceta/index

Gobierno del Distrito Federal. (2008c). Declaratoria de necesidad para la prestación del servicio de transporte público colectivo de pasajeros en el corredor de transporte público de pasajeros "Metrobús eje 4 Sur" Anexo a la declaratoria de necesidad para la prestación del servicio de transporte público colectivo de pasajeros en el corredor de transporte público de pasajeros "Metrobús eje 4 Sur". Gaceta Oficial del Distrito Federal. Número 480. Décimo Séptima Época. Retrieved from http://www.consejeria.df.gob.mx/uploads/gacetas/julio/gaceta/index

Gobierno del Distrito Federal. (2010a). Aviso por el que se da a conocer el balance entre la oferta y la demanda de transporte público colectivo de pasajeros en el corredor "Metrobús Eje 1 Poniente". Gaceta Oficial del 
Distrito Federal. Número 993. Décimo Séptima Época. Retrieved from http://www.consejeria.df.gob.mx/uploads/gacetas/agosto/gaceta/index

Gobierno del Distrito Federal. (2010b). Declaratoria de necesidad para la prestación del servicio de transporte público colectivo de pasajeros en el corredor de transporte público de pasajeros "Metrobús Eje 1 Poniente". Anexo a la "Declaratoria de necesidad para la prestación del servicio de transporte público colectivo de pasajeros en el corredor de transporte público de pasajeros "metrobús Eje 1 Poniente". Gaceta Oficial del Distrito Federal. Número 993.Décimo Séptima Época. Retrieved from http://www.consejeria.df.gob.mx/uploads/gacetas/diciembre/gaceta/index

Gobierno del Distrito Federal. (2011a). Aviso por el que se da a conocer el balance entre la Oferta y la Demanda de Transporte Público Colectivo de Pasajeros en el corredor "Metrobús Buenavista-Centro Histórico-San Lázaro-Aeropuerto". Gaceta Oficial del Distrito Federal. Número 1205. Décimo Séptima Época. Retrieved from http://www.consejeria.df.gob.mx/uploads/gacetas/diciembre/gaceta/index

Gobierno del Distrito Federal. (2011b). Metrobús Línea 4 Buenavista-San Lázaro-Aeropuerto. Retrieved from http://www.metrobus.df.gob.mx/docs/documentos_L4/MB-L4_ATNO_26082011.pdf

Gobierno del Distrito Federal. (2011c). Plan Integral de Manejo de la Ciudad de México. Transporte Público. Retrieved from http://www.metrobus.df.gob.mx/docs/documentos_L4/Anexos/Anexo_Trece.pdf

Gobierno del Distrito Federal and Banco Mundial. (sin año). Programa de Mitigación y Recuperación Urbana del Metrobús Insurgentes. Retrieved from http://www-wds.worldbank.org/servlet/WDSConytenet Server/WDSP/IB/2005/12/07/000012009_20051207/RP3720rev20pdf.pdf

Gobierno del Distrito Federal, Secretaría de Medio Ambiente y Secretaría de Transportes y Vialidad. (2004). Diseño conceptual, funcional operacional y proyecto ejecutivo del corredor estratégico Insurgentes.

Hidalgo, D., \& Graftieaux P. (2009). Bus Rapid Transit Systems in Latin America and Asia Results and Difficulties in 11 Cities. Journal of the Transportation Research Board, 77-88.

Institute for Transportation and Development Policy. (2010a). Bus Rapid Transit Planning Guide. Retrieved from http://www.itdp.org

Institute for Transportation and Development Policy. (2010b). What we do public transportation. Retrieved from http://www.itdp.org/who-we-are

Iracheta, A. (2006). La Necesidad de una Politica Pública para el desarrollo de Sistemas Integrados de Transporte en las Grandes Ciudades Mexicanas. México: Instituto Nacional de Ecología, Centro Mario Molina para Estudios Estratégicos sobre energía y Medio Ambiente, A. C., Centro de Transporte Sustentable y con la Fundación William y Flora Hewlett.

Jarzab, J, Lightbody J., \& Maeda E. (2002). Characteristics of Bus Rapid Transit Projects: An Overview. Public Journal of Transportation, 2(5), 31-46.

Lámbarry, F., Rivas, A., \& Trujillo, M. (2011). Institutional Aspects on Bus Rapid Transit systems Implementation in Mexico City, Estado de México and Leon Guanajuato. Journal of Management and Strategy, 1(1), 93-109.

Lámbarry, F., Rivas, L., \& Peña, M. (2011). Planeación de los sistemas BRT y consensos entre transportistas y autoridades de gobierno durante su implementación: el caso de Metrobús y Mexibús. Administración \& Desarrollo, 39(54), 133-150.

Lámbarry, F., Rivas, A., \& Trujillo, M. (2012). Conflict Resolution Through Consensus building approach in the Implementation of bus Rapid Transit System. International Journal of Business and Management, 7(14),1-17.

Levinson, H., Zimmerman, S., Clinger, J., Gast, J., Rutherford, S., \& Bruhn, E. (2003). Bus Rapid Transit, Volume 2: Implementation Guidelines. Transit Cooperative Research Program (TCRP) Chapter 90. Washington: Transportation Research Board

Menckhoff, G. (2005). Latin American Experience with bus rapid transit. Gerhard Proceedings of the Annual Meeting. Institute of Transportation Engineers. Melbourne, Australia, August.

Metrobús. (2011). Ley de Transparencia y Acceso a la Información. Artículo 14. Fracción XI Pública Retrieved from http://www.metrobus.df.gob.mx/transparencia/art14_XI.html

Metrobús. (2011). Organización. Retrieved from http://www.Metrobús.df.gob.mx/organizacion.html 
Molina, L., \& Molina, M. (1994). Air Quality in the México, Mega City: an integrated Assessment. Boston, MA EUA: Kluwer Academic Publichers.

Polzin, S., Baltes, M., \& Vuchic, V. (2002). Bus Rapid Transit: A Viable Alternative? Journal of public Transportation, 5(2), 47-70.

Rivas, L., Chávez, E., Maldonado, H., Chávez, A., Carmona, T., Cienfuegos S., \& Molina, G. (2007). Incentivos y desincentivos en los sistemas de transporte público en Londres, Madrid y Ciudad de México. Innovar, $17(30), 113-132$.

Secretaría del Medio Ambiente. (2004). Resolución administrativa. Número de expediente: DIR-MG-1300/2004

Secretaría del Medio Ambiente. (2007). Resolución administrativa. Número de expediente: DEIA-MG-491/2007

Secretaría del Medio Ambiente. (2009). Resolución administrativa. Número de expediente: DEIA-MG-0909/2009

Secretaría del Medio Ambiente. (2011). Resolución administrativa. Número de expediente: DEIA-IP-183/2011

Secretaría de Transporte y Vialidad. (2010). Acuerdo por el que se expide el Programa Integral de Transporte y Vialidad 2007-2012. Gaceta Oficial del Distrito Federal. Número 803 Bis. Décima Séptima Época. Retrieved from http://www.consejeria.df.gob.mx/uploads/gacetas/diciembre/gaceta/index

Secretaría de Transporte y Vialidad. (2011). Gobierno del Distrito Federal y Concesionarios de las Rutas 1, 3 y 88, firmaron Acuerdos de Participación para la Línea 3 del Metrobús. Retrieved from http://www.setravi.df.gob.mx/wb/stv/noticias

Transportation Research Board. (2012). About TRB. Retrieved from http://www.trb.org/AboutTRB/AboutTRB.aspx

Transportation Research Board. (2003).Transit Cooperative Research Program Report 90. Bus Rapid Transit Volume 2: Implementation Guidelines. Washington, D.C. Retrieved from http://www.TRB.org

\section{Copyrights}

Copyright for this article is retained by the author(s), with first publication rights granted to the journal.

This is an open-access article distributed under the terms and conditions of the Creative Commons Attribution license (http://creativecommons.org/licenses/by/3.0/). 